
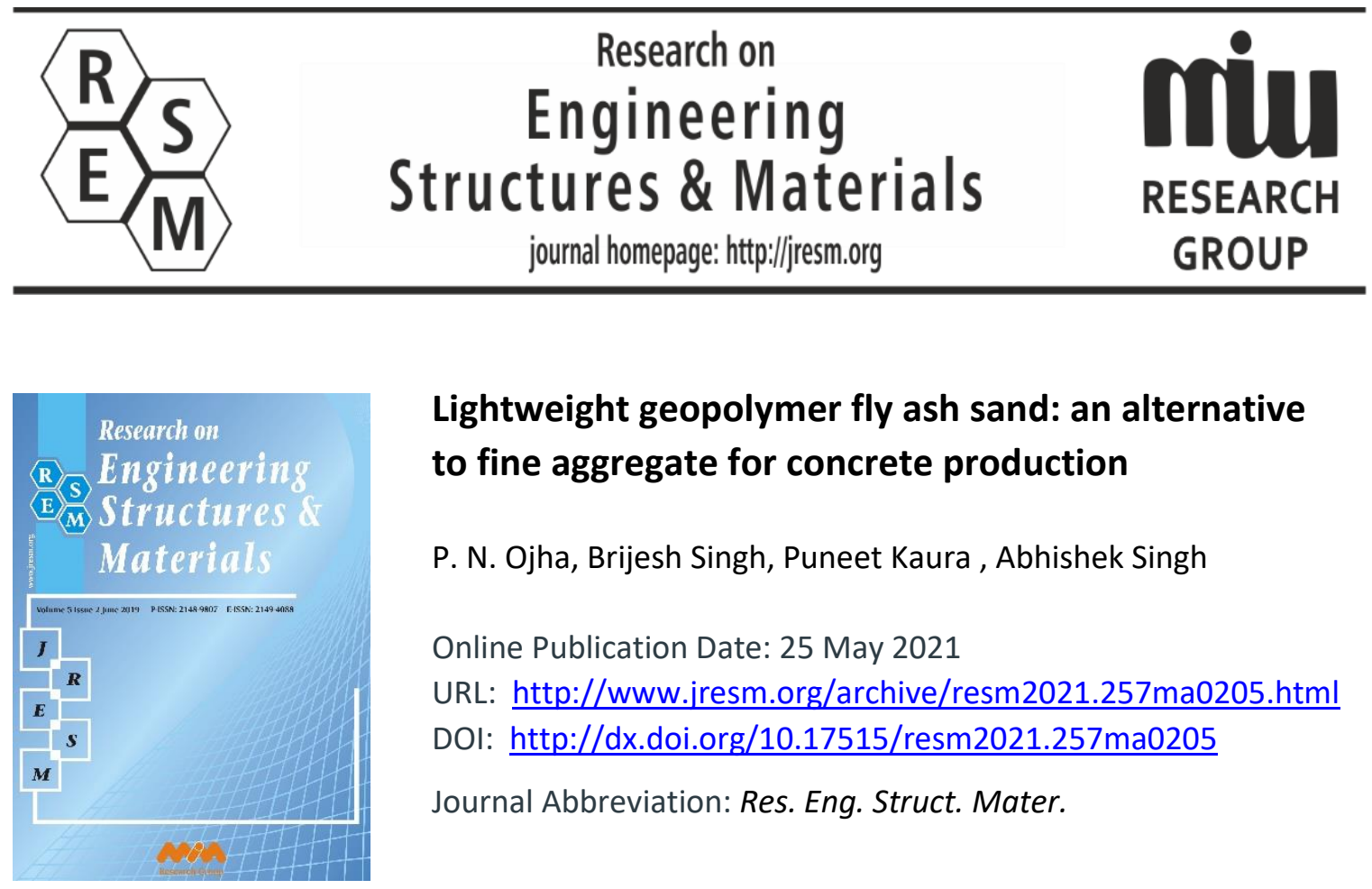

\title{
Lightweight geopolymer fly ash sand: an alternative to fine aggregate for concrete production
}

P. N. Ojha, Brijesh Singh, Puneet Kaura, Abhishek Singh

Online Publication Date: 25 May 2021

URL: http://www.jresm.org/archive/resm2021.257ma0205.html

DOI: http://dx.doi.org/10.17515/resm2021.257ma0205

Journal Abbreviation: Res. Eng. Struct. Mater.

\section{To cite this article}

Ojha PN, Singh B, Kaura P, Singh A. Lightweight geopolymer fly ash sand: an alternative to fine aggregate for concrete production. Res. Eng. Struct. Mater., 2021; 7(3): 375-391.

\section{Disclaimer}

All the opinions and statements expressed in the papers are on the responsibility of author(s) and are not to be regarded as those of the journal of Research on Engineering Structures and Materials (RESM) organization or related parties. The publishers make no warranty, explicit or implied, or make any representation with respect to the contents of any article will be complete or accurate or up to date. The accuracy of any instructions, equations, or other information should be independently verified. The publisher and related parties shall not be liable for any loss, actions, claims, proceedings, demand or costs or damages whatsoever or howsoever caused arising directly or indirectly in connection with use of the information given in the journal or related means.

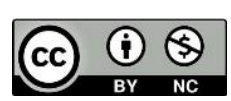

Published articles are freely available to users under the terms of Creative Commons Attribution - NonCommercial 4.0 International Public License, as currently displayed at here (the "CC BY - NC"). 


\title{
Research on Engineering Structures \& Materials
}

journal homepage: http://jresm.org

Research Article

\section{Lightweight geopolymer fly ash sand: an alternative to fine aggregate for concrete production}

\author{
P. N. Ojha a, Brijesh Singh ${ }^{*}$, Puneet Kaura ${ }^{c}$, Abhishek Singh ${ }^{d}$
}

National Council for Cement and Building Materials, India

\begin{tabular}{|c|c|}
\hline & Abstract \\
\hline & \multirow{13}{*}{$\begin{array}{l}\text { The current study is aimed to evaluate and critically analyze the properties of } \\
\text { Light Weight Geopolymer Fly Ash Sand (LWGFAS). LWGFAS has been prepared } \\
\text { by geopolymerisation of the fly ash. Liquid solution of } 4 \mathrm{M} \mathrm{NaOH} \text {, and } \\
\mathrm{Na} 2 \mathrm{SiO} 3 / \mathrm{NaOH}=2 \text { was used as an activator and post set heat treatment of } 1 \text { hour } \\
\text { at } 100{ }^{\circ} \mathrm{C} \text { was applied for preparation of LWGFAS. The LWGFAS sample was } \\
\text { analyzed for different physical and chemical parameters along with studies on } \\
\text { mineralogy and alkali silica reactivity. The molar concentration of activator } \\
\text { solution and duration of post set heat treatment plays vital role on the physical } \\
\text { and mechanical properties (particularly specific gravity, bulk density and water } \\
\text { absorption) of the Geopolymer fly ash sand. The specific gravity and water } \\
\text { absorption of LWGFAS were } 1.57 \text { and } 17.85 \% \text { respectively. Experimental } \\
\text { concrete mixes made with LWGFAS as a replacement of natural sand were } \\
\text { evaluated for compressive strength and different durability properties of } \\
\text { concrete. The study indicates that LWGFAS can be suitable for a wide range of } \\
\text { applications in making concrete ranging from light weight in nature to normal } \\
\text { weight concrete based on the physical and chemical characteristics of } \\
\text { Geopolymer Fly Ash Sand. }\end{array}$} \\
\hline Article history: & \\
\hline & \\
\hline & \\
\hline & \\
\hline Keywords: & \\
\hline & \\
\hline opolymer Fly Ash & \\
\hline & \\
\hline Water Absorption; & \\
\hline & \\
\hline & \\
\hline & \\
\hline
\end{tabular}

(C) 2021 MIM Research Group. All rights reserved.

\section{Introduction}

Depletion of the natural minerals and the over usage of the natural sources are consequences of the usage of the M-sand (Manufactured sand) and the natural sand respectively which in turn adversely affect the environmental balance that makes a call to identify the ideal replacement material for fine aggregate in the concrete preparation [1]. Worldwide consumption of concrete is estimated to be about 11.5 billion tons per year and by year 2050 it is expected to reach to 18 billion tons of concrete per year [2]. However, as per the Cement Sustainability Initiative (CSI) report-2009 by World Business Council for Sustainable Development, the annual consumption of concrete worldwide has gone upto 25 billion tons of concrete per year-by-year 2009 [3]. In order to achieve sustainability in construction industry, the use of alternate materials should be focused with comprehensive approach. Fine aggregate is an essential material in the concrete production. From many decades, river sand is used as fine aggregate but dredging of sand from river beds is adversely affecting environment across the world. Donza et al. [4] reported an increase in compressive strength of concrete mix by 10-15\%, when crushed stone sand was used as a $100 \%$ replacement of natural sand. Such results led to increase in use of quarry dust as fine aggregate in concrete. However, particulate matter emitted from crushing units during mining and crushing of the stones for crushed sand causes air pollution and usage of heavy machinery during this process leads to noise, thereby causing

\footnotetext{
${ }^{*}$ Corresponding author: brijeshsehwagiitr96@gmail.com

a orcid.org/0000-0003-1754-4488; b orcid.org/0000-0002-6512-1968; c orcid.org/0000-0001-7237-8043;

d orcid.org/0000-0002-2343-5934

DOI: http://dx.doi.org/10.17515/resm2021.257ma0205
}

Res. Eng. Struct. Mat. Vol. 7 Iss. 3 (2021) 375-391 
negative impact on the environment. The fly ash generation in India through thermal power plants in 2014-15 was about 185 million tons and utilization was 55.69\% [5, 6].

Research has been carried out for the use of waste material like bottom ash, construction and demolition waste, copper slag, iron and steel slag as a fine aggregate $[7,8,9,10]$. Another alternative could be use of sintered fly ash lightweight aggregate which is now commercially available for use in structural concrete with an upper ceiling on grade of concrete in Indian specification IS 9142 Part 2 [11]. Along with the problem on the scarcity of natural river sand and finding its alternatives, growth of the construction and infrastructure industry throughout the globe is demanding the need to examine the feasibility of using other alternatives such as fly ash-geopolymerization reactions to produce fine aggregates as an alternative to natural sand. The geopolymerisation of the fly ash is the process wherein the fly ash is mixed with alkaline activator solution consisting of the hydroxides and the silicates which dissolves and transforms the vitreous phase present in the fly ash in to a three dimensional structure, leading to the solidification of the material [12-15]. Due to their lower calcium content, they are more resistant to acid attack than Portland cement-based materials [16]. Limited number of studies related to manufacture and the use of the fly ash based geopolymer sand for construction purpose have been conducted by the researchers till date. Rao et al. [17] performed studies on characterization of geopolymer sand which was prepared on laboratory scale using fly ash. Similar study was also carried out by Agrawal et al. [18], where geopolymer sand was prepared on commercial scale and was characterized for its different parameters such as water absorption, specific gravity, soundness, particle size distribution etc. In both of these studies, preparation of fly ash based geopolymer sand was done using $10 \mathrm{M} \mathrm{NaOH}$ solution. On comparison of physical characteristics of river sand with geopolymer fly ash sand, it was observed that both fine aggregates had similar grain size distribution and specific gravity values.

The molar concentration of activator solution plays a very vital role on the mechanical properties of the product obtained from geopolymerisation. Higher concentration of activator leads to Geopolymeric products of higher strength, density (specific gravity) and lower water absorption [19]. Apart from molar concentration, heat treatment after initial mixing and granulation plays a vital role on the physical and mechanical properties of the final product. Rao et al. [17] heated cohesive mass (slurry formed from mixing fly ash with activator solution dried for 4 hours) obtained through $4 \mathrm{~mm}$ mesh at $100 \mathrm{oC}$ for 7 days in a temperature-controlled oven to complete geopolymerisation reaction. Physical properties (specific gravity and bulk density) of geopolymer fly ash sand obtained from usage of high molar concentration and extended post-set heat treatment were comparable to conventional natural sand. However, preparation of geopolymer fly ash sand with activator solutions of very high molar concentrations and applying post set heat treatment for extended duration may not be the cost-effective approach while developing geopolymer fly ash sand as an alternative to the river sand.

\section{Research Significance}

Based on the literature studied, it was observed that only limited studies has been done on Geopolymer Fly ash sand. Research work to lower the molar concentrations and duration of post set heat treatment applied to Geopolymeric product while production of geopolymer fly ash sand shall be done in order to lower the production cost, without compromising the quality of the final product. Hence, in this study geopolymer fly ash sand was prepared with lower concentration of activator solution and significantly lower duration of post set heat treatment. In the current study, Light Weight Geopolymer Fly Ash Sand (LWGFAS) was evaluated as a potential alternative to natural fine aggregate. In the present investigation, characterization of LWGFAS was done for assessing its suitability to 
be used in concrete and mortar. Further, concrete mixes containing geopolymer fly ash sand as replacement of natural sand were prepared and evaluated for different hardened and durability parameters and their performance was compared with control concrete mix made with $100 \%$ natural sand. Studies were also carried out on different grades of mortar prepared with LWGFAS and their subsequent comparison with mortar prepared with natural sand.

\section{Preparation of Light Weight Geopolymer Fly Ash Sand (LWGFAS)}

The geopolymerisation process depends on the reactivity and concentration of alkaline activator. The alkali-enrichment in lightweight geopolymer fly ash sand increases pore structure development of the concrete system, which considerably affects the sample with less water to binder ratio. Furthermore, the increase in alkalinity results in the degradation of mechanical strength. Therefore, the quantity of alkaline activators needs to be considered wisely while designing the light weight geopolymer fly ash concrete mix. In current study, Lightweight Geopolymer fly ash sand (LWGFAS) was prepared by using class F fly ash and alkaline activator solution. The fly ash used in the study was from NTPC Sipat, India. The specific gravity and Blaine's fineness of fly ash was $2.12 \& 382 \mathrm{~m}^{2} / \mathrm{kg}$ respectively. On the basis of $\mathrm{SiO}_{2}(52.32 \%), \mathrm{Al}_{2} \mathrm{O}_{3}(26.29 \%)$, and $\mathrm{CaO}$ (5.83\%) contents, fly ash is categorized as Class $\mathrm{F}$. The alkaline solution was prepared by mixing sodium hydroxide pellets (purity 90\%) to water (4 M), and then adding sodium silicate $\left(\mathrm{Na}_{2} \mathrm{SiO}_{3}\right)$ solution to it with $\mathrm{SiO}_{2}: \mathrm{Na}_{2} \mathrm{O}=2\left(\mathrm{SiO}_{2}=29.8 \%, \mathrm{Na}_{2} \mathrm{O}=14.98 \%\right)$. The ratio of sodium silicate solution to sodium hydroxide solution was 2 by weight [20]. Lightweight Geopolymer fly ash sand (LWGFAS) was prepared by mixing the fly ash in the alkaline solution $\mathrm{NaOH}+$ $\mathrm{Na}_{2} \mathrm{SiO}_{3}$ ). The molarity of $\mathrm{NaOH}$ and ratio of $\mathrm{Na} 2 \mathrm{SiO} 3: \mathrm{NaOH}$ was kept constant to $4 \mathrm{M}$ and 2:1 respectively to make GFS cost effective. The alkaline activator solution was prepared and stored for $24 \mathrm{~h}$ prior to mixing it with the fly ash. Fly ash was heated up to a temperature of $60^{\circ} \mathrm{C}$ and mixed with the alkaline activator solution the ratio of 3:1 respectively. Elevating the curing temperature to $60^{\circ} \mathrm{C}$ increases the extent and rate of reaction, through an increase in mesopore volume, surface area and an accelerated setting time. The kinetics appears to be temperature-controlled only before the material is hardened. The mixing was done in a centrifugal mixer machine wherein the fly ash was mixed with the alkaline solution for 10 minutes to produce a dry mix having workability of 24-30 s as per Vee-Bee Consistometer test. After the mixing, the dry mix was transferred to a vibro-sifter wherein the mix was vibrated and passed through $4.75 \mathrm{~mm}$ and $2.36 \mathrm{~mm}$ IS sieve to yield particles of varying size similar to the shape and size of the river sand. These particles were then heated to a temperature of about $100{ }^{\circ} \mathrm{C}$ for about one hour to harden the granules which are termed as LWGFAS as shown in Figure 1.

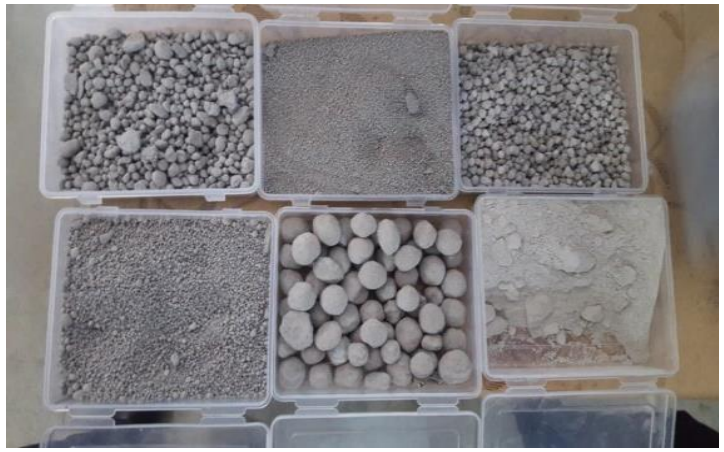

Fig. 1 Different Sizes of Light Weight Geopolymer Fly ash Sand (LWGFAS) 


\section{Experimental Work}

The characterization of Light Weight Geopolymer Fly Ash Sand was performed. The LWGFAS was evaluated for various chemical and physical parameters as per IS 383: 2016 given in Table $1 \& 2$. The study also includes petrographic and mineralogical analysis of LWGFAS as per IS 2386 part VIII [21] and accelerated mortar bar test as per ASTM C1260 [22] to evaluate the expansion due to alkali-aggregate reactivity of LWGFAS. Other materials like cement sample, coarse aggregates, fine aggregates, chemical admixture were also tested for various physical and chemical parameters and were found conforming to their respective Indian and ASTM standards. The study also investigates the performance of concrete and mortar samples prepared with LWGFAS as fine aggregate. It has been compared with similar concrete and mortar samples prepared using river sand as fine aggregate. The durability studies on hardened concrete also evaluates the long term comparative behaviour of concrete made with LWGFAS with similar samples made with river sand.

\section{Test Results and Discussion}

\subsection{Characterization of Light Weight Geopolymer Fly Ash Sand}

The light weight geopolymer fly ash sand is evaluated for various chemical and physical parameters as per IS 383[23]. The results of physical and chemical analysis along with sieve analysis for LWGFAS are given in table 1 and 2 respectively.

Table 1. Physical and Chemical Test Results of Light Weight Geopolymer Fly Ash Sand

\begin{tabular}{|c|c|c|c|}
\hline Sl. No. & Test Carried out & Result Obtained & $\begin{array}{l}\text { Permissible Limits as } \\
\text { Per IS: 383-2016 }\end{array}$ \\
\hline 1 & Specific gravity & 1.57 & $2.1-3.2$ \\
\hline 2 & Water absorption, $\%$ & 17.85 & 5 \\
\hline 3 & $\begin{array}{c}\text { Material finer than 75-micron, } \\
\%\end{array}$ & 2.4 & 10.0 \\
\hline 4 & Soundness, Na2SO4 \% & 5.07 & 10 \\
\hline 5 & Organic impurities & Nil & -- \\
\hline 6 & Clay Lumps, $\%$ & Nil & 1 \\
\hline 7 & $\begin{array}{l}\text { Total deleterious material, } \% \\
\text { (except coal \& lignite) }\end{array}$ & 2.4 & 2 \\
\hline 8 & Silt by CPWD \% & 0.9 & \\
\hline 9 & Loss of Ignition (LOI) & 3.12 & -- \\
\hline 10 & Silica $\left(\mathrm{SiO}_{2}\right)$ & 58.52 & -- \\
\hline 11 & Iron oxide $\left(\mathrm{Fe}_{2} \mathrm{O}_{3}\right)$ & 3.55 & -- \\
\hline 12 & Aluminium oxide $\left(\mathrm{Al}_{2} \mathrm{O}_{3}\right)$ & 22.94 & -- \\
\hline 13 & Calcium oxide $(\mathrm{CaO})$ & 5.24 & -- \\
\hline 14 & Magnesium oxide (MgO) & 0.99 & 6.0 (Max) \\
\hline 15 & Sulphate $\left(\mathrm{SO}_{3}\right)$ & 0.30 & 0.5 (Max) \\
\hline 16 & Total Alkalis as $\mathrm{Na}_{2} \mathrm{O}$ eq. & 3.37 & 0.3 (Max) \\
\hline 17 & Chloride & 0.030 & 0.040 (Max) \\
\hline
\end{tabular}


Table 2. Sieve Analysis Results of Light Weight Geopolymer Fly Ash Sand

\begin{tabular}{ccc}
\hline & Percentage Passing & $\begin{array}{c}\text { Percentage Passing for grading zone II as per } \\
\text { IS 383-2016 }\end{array}$ \\
\hline $10 \mathrm{~mm}$ & 100 & 100 \\
$4.75 \mathrm{~mm}$ & 100 & $90-100$ \\
$2.36 \mathrm{~mm}$ & 97 & $75-100$ \\
$1.18 \mathrm{~mm}$ & 79 & $55-90$ \\
$600 \mu$ & 48 & $35-59$ \\
$300 \mu$ & 20 & $8-30$ \\
$150 \mu$ & 6 & $0-20$ \\
Zone & & Zone II \\
\hline
\end{tabular}

The specific gravity of LWGFAS is 1.57 and a loose bulk density of $780 \mathrm{~kg} / \mathrm{m} 3$ which suggests that it is a light weight aggregate [24]. The specific gravity of geopolymer fly ash sand reported in literature [18] are higher than the geopolymer fly ash sand in this study.

It was observed that the specific gravity of the LWGFAS was observed as 1.57 which was comparatively less as compared to the river sand. The study conducted by Agrawal et al. [18] produced geopolymer fly ash sand with specific gravity as 2.46 . The reduction in the specific gravity may be accounted due to the decrease in the molarity of the $\mathrm{NaOH}$. The molarity of the $\mathrm{NaOH}$ is directly proportional to the strength of the geopolymer concrete, the geopolymer sand preparation was carried out using $10 \mathrm{M}$ of $\mathrm{NaOH}$ solution, which may not be the cost effective alternative to the river sand. Along with higher concentration $(10$ M) of activator solutions, extended duration of post set heat treatment was applied to prepare the geopolymer fly ash sand in studies conducted by Agrawal et al [18]. However, in this study $4 \mathrm{M} \mathrm{NaOH}$ solution and only 1 hour of post set heat treatment at $100 \mathrm{oC}$ was used for preparation of LWGFAS leading to lower specific gravity and higher water absorption. Due to lower specific gravity and high water absorption, use of LWGFAS may be restricted to concrete strength upto $35 \mathrm{MPa}$.

The values of water absorption (17.85\%) and total deleterious materials $(2.4 \%)$ are observed to be quite higher than the permissible limits of $5 \%$ and $2 \%$ respectively for manufactured aggregate as per IS:383-2016. The high value of water observation indicates the presence of voids in its molecular structure. It supports the light weight nature of the geopolymer fly ash sand sample. The chemical analysis of geopolymer fly ash sand indicates its high alkali content, $3.37 \%$ as total Na2O equivalent, quite evident from its alkaline process of manufacturing. As per results of sieve analysis, LWGFAS falls in grading zone II.

\subsubsection{Petrographic and Mineralogical Analysis}

Petrographic and mineralogical analysis of LWGFAS was carried out using Optical microscope as per IS 2386 part VIII. It was observed that the LWGFAS is a fine grained textured and the minerals present in order of their abundance are opaque minerals, calcite, quartz, plagioclase-feldspar, orthoclase-feldspar and iron oxide. Subhedral to anhedral opaque minerals with corroded margins were uniformly distributed in the sample. Majority of opaque minerals were in the size range of $150 \mu \mathrm{m}$ to $250 \mu \mathrm{m}$. Micro globular calcite grains with rounded margins were present as clusters in the sample. These clusters were brittle and fragile in nature and uniformly distributed in the sample. Subhedral to anhedral quartz grains with sharp angular margins were well graded and inhomogeneously distributed. Majority of quartz grains were in the size range of $100 \mu \mathrm{m}$ to $200 \mu \mathrm{m}$. Prismatic plagioclase and subhedral orthoclase grains were fresh in nature. Anhedral to subhedral iron oxide grains with rounded grain margins were randomly distributed. Mica Content (\% by weight) was found to be nil. Modal composition has been 
tabulated in Table 3 below. The microphotographs are given in figure 2 and 3 . The strained quartz percentage is about $11 \%$ and their Undulatory Extinction Angle (UEA) varies from 120 to 140, which indicates that aggregates are non-reactive and not prone to expansion due to alkali aggregate reaction. The mineralogical composition, strained quartz percentage and UEA are similar to natural sand when compared with limits given IS 383: 2016.

Table 3. Modal Composition of LWGFAS (Results in \%)

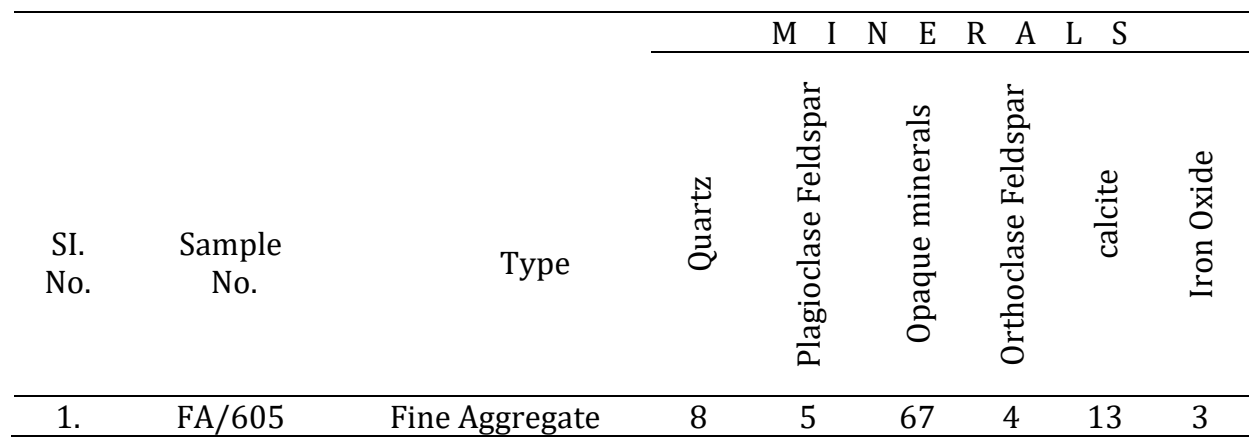

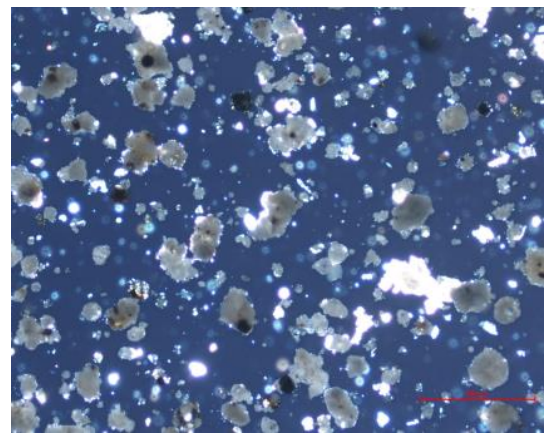

Fig. 2 FA (Plate-1): Distribution of

Mineral Grains in LWGFAS. (5x, $\mathrm{x}$-Nicols)

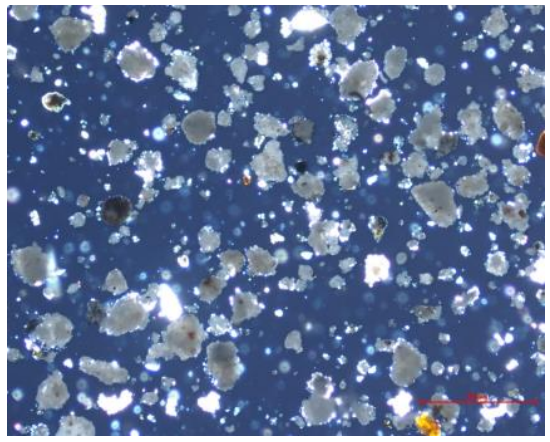

Fig. 3 FA (Plate-2): Distribution of

Mineral Grains in LWGFAS. (5x, x-Nicols)

\subsubsection{Accelerated Mortar Bar Test}

Accelerated mortar bar test was performed as per ASTM C1260 to evaluate the expansion due to alkali-aggregate reactivity of LWGFAS. The results of accelerated mortar bar test, given in table 4 shows an expansion of $0.02 \%$ at 16 days after casting, lower than the permissible limit of $0.1 \%$ thus indicating innocuous nature of LWGFAS. However, high alkali content as observed in chemical analysis may aggravate alkali-silica expansion in concrete with doubtful or reactive coarse aggregate. The suspected behavior can be analyzed under long term testing using prism bar test as per ASTM C1293 [25].

Table 4. Accelerated Mortar Bar Test (as per ASTM C1260)

\begin{tabular}{cccc}
\hline S. No. & Sample Type & 1N NaOH 800C & Remarks \\
\hline 1 & $\begin{array}{c}\text { Light Weight Geo polymer fly ash } \\
\text { sand }\end{array}$ & 0.02 & Innocuous \\
\hline
\end{tabular}




\subsubsection{Long Term Prism Bar Test}

The prism bar test was conducted using the standard mix prescribed in ASTM C 1293. The standard mix has a cement content of $420 \mathrm{~kg} / \mathrm{m} 3$ with an alkali content of $0.9 \pm 0.1$ percent and a water/cement ratio in the range of 0.42 to 0.45 by mass. A sufficient amount of sodium hydroxide is added to the water used for the concrete mix to increase the cement alkali content to 1.25 percent. The reading was taken for one year. An average expansion is calculated from measurements on three replicate specimens. If the average expansion of the three concrete bars is equal to or greater than 0.04 percent at an age of one year, then the aggregate is considered to be potentially reactive. The results of prism bar test are given in figure 4. On perusal of expansion results, it was seen that expansion results of the fine aggregate samples, natural sand and LWGFAS (with innocuous coarse aggregates and doubtful coarse aggregates) are comparable at all ages and below the permissible limit of $00.04 \%$ at one year.

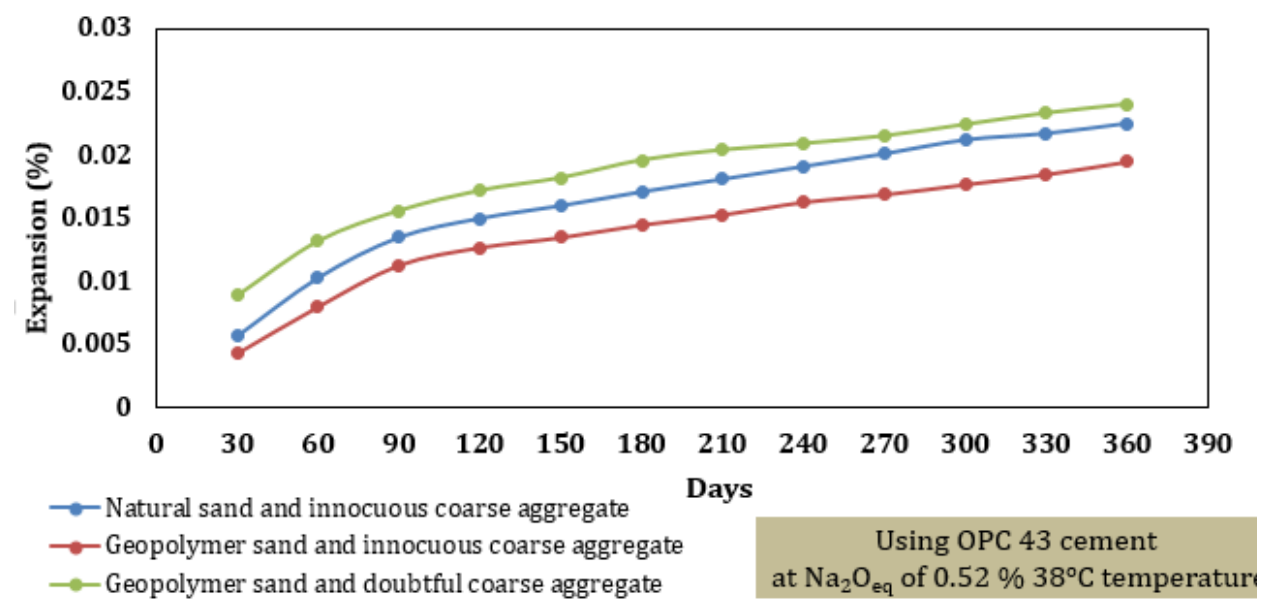

Fig. 4 Prism bar test (as per ASTM C 1293)

\subsection{Hardened Concrete Properties}

In this investigation two mixes of M25 grade were prepared, i.e. control mix with river sand as fine aggregate and experimental mix with LWGFAS as fine aggregate. Locally available cement sample (OPC-43 Grade without any performance improver, conforming to IS 269 [26]), coarse aggregates and a naphthalene based chemical admixture was used for preparation of both the mixes. All the component materials conform to their respective. The mix proportioning was done keeping the absolute volume constant to study the effect of LWGFAS and river sand on concrete properties. The mix proportion used is given in Table 5. 
Table 5. Mix Proportion Used for Casting of Mixes

\begin{tabular}{|c|c|c|}
\hline $\begin{array}{c}\text { Mix Constituents } \\
\text { (kg/one cubic meter) }\end{array}$ & $\begin{array}{l}\text { M25 with natural fine } \\
\text { aggregate } \\
\text { (Control Mix) }\end{array}$ & $\begin{array}{c}\text { M25 with } 100 \% \\
\text { replacement of natural } \\
\text { fine aggregate with } \\
\text { LWGFAS (Experimental } \\
\text { Mix) }\end{array}$ \\
\hline Cement (OPC-43 grade) & 320 & 320 \\
\hline Water & 160 & 160 \\
\hline $\begin{array}{c}\text { Fine Aggregate } \\
\text { (Natural Sand/Geopolymer Fly } \\
\text { ash Sand) } \\
\text { Coarse Aggregate }\end{array}$ & $\begin{array}{c}833 \\
\text { (Abs. vol. } 0.3157 \mathrm{~m}^{3} \text { ) }\end{array}$ & $\begin{array}{c}499 \\
\text { (Abs. vol. } 0.3166 \mathrm{~m}^{3} \text { ) }\end{array}$ \\
\hline Fraction -I) 20mm (60\%) & 632 & 631 \\
\hline Fraction -II) $10 \mathrm{~mm}(40 \%)$ & 517 & 516 \\
\hline $\begin{array}{l}\text { Chemical Admixture @ by wt. of } \\
\text { cementitious }\end{array}$ & $\begin{array}{l}2.56 \text { (dosage at rate of } \\
0.8 \% \text { by weight of } \\
\text { cementitious) }\end{array}$ & $\begin{array}{l}5.12 \text { ( dosage at rate of } \\
1.6 \% \text { by weight of } \\
\text { cementitious) }\end{array}$ \\
\hline Water - Cementitious Ratio & 0.50 & 0.50 \\
\hline $\begin{array}{l}\text { Workability obtained in terms of } \\
\text { slump (after } 90 \text { mins of } \\
\text { retention period) }\end{array}$ & $80-90 \mathrm{~mm}$ & $90-100 \mathrm{~mm}$ \\
\hline Average fresh density $\left(\mathrm{kg} / \mathrm{m}^{3}\right)$ & 2485 & 2245 \\
\hline
\end{tabular}

The two mixes, i.e. control and experimental mix were evaluated for following tests to study the performance of LWGFAS with respect to river sand as fine aggregate in concrete. The workability of the experimental mix and control mix was varying from 90-100 $\mathrm{mm}$ and 80-90 mm respectively. In case of experimental mix higher dosage of chemical admixture was required to achieve the same workability. It may be attributed to the irregular shape and rough texture of geopolymer fly ash sand [27].

\subsubsection{Compressive Strength}

The test was conducted on concrete cubes (of size $150 \mathrm{~mm}$ X $150 \mathrm{~mm}$ X $150 \mathrm{~mm}$ ) as per IS: 516 . Three concrete cubes were tested at $3,7,28,56 \& 90$ days. The test results are given in Table 6. The compressive strength at 3 days in experimental mix is $51.68 \%$ of that of control sample while the compressive strength at 28 days in experimental mix is $74.90 \%$ of that of control sample. The observed gain from 7 to 28 days' strength may be attributed to the unreacted fly ash particles present in the sand which may have reacted with the cement hydration product such as lime and may have contributed to the later strength. The maximum pozzolanic activation activities of the fly ash occur between 56 to 90 days. Therefore, the continuous increase in concrete made with LWGFAS upto 90 days may be due to the late gain of strength by the fly ash present in the system $[27,28]$. As discussed earlier, in this study $\mathrm{NaOH}$ solution of lower concentration and only 1 hour of post set heat treatment at $100^{\circ} \mathrm{C}$ was used for preparation of LWGFAS leading to lower specific gravity and higher water absorption, which might be the reason for lower compressive strength of experimental mixes containing LWGFAS in comparison to control concrete mixes containing natural sand. 
Table 6. Compressive Strength Results

\begin{tabular}{|c|c|c|c|c|c|c|}
\hline $\begin{array}{l}\text { Sl. } \\
\text { No. }\end{array}$ & $\begin{array}{l}\text { Age of } \\
\text { testing }\end{array}$ & $\begin{array}{l}\text { M25 with } \\
\text { natural } \\
\text { fine } \\
\text { aggregate } \\
\text { (Control } \\
\text { Mix) } \\
\text { Average } \\
\text { Value }\end{array}$ & $\begin{array}{l}\text { Standard } \\
\text { deviation } \\
\text { M25 with } \\
\text { natural fine } \\
\text { aggregate }\end{array}$ & $\begin{array}{l}\text { M25 with } 100 \% \\
\text { replacement of } \\
\text { natural fine } \\
\text { aggregate with } \\
\text { LWGFAS } \\
\text { (Experimental } \\
\text { Mix) } \\
\text { Average } \\
\text { Value }\end{array}$ & $\begin{array}{c}\text { Standard } \\
\text { Deviation } \\
\text { M25 with } \\
100 \% \\
\text { replacement } \\
\text { of natural fine } \\
\text { aggregate } \\
\text { with LWGFAS }\end{array}$ & $\begin{array}{c}\text { Percentage } \\
\text { Compressive } \\
\text { Strength } \\
\text { (Experimental } \\
\text { Mix/Control } \\
\text { Mix)*100 } \\
\text { Average } \\
\text { Value }\end{array}$ \\
\hline 1. & 3 days & $19.87 \mathrm{MPa}$ & 1.05 & $10.27 \mathrm{MPa}$ & 0.85 & 51.68 \\
\hline 2. & 7 days & $24.23 \mathrm{MPa}$ & 1.25 & $13.49 \mathrm{MPa}$ & 1.15 & 55.67 \\
\hline 3. & 28 days & $36.06 \mathrm{MPa}$ & 1.41 & $27.01 \mathrm{MPa}$ & 1.75 & 74.90 \\
\hline 4. & 56 days & $40.51 \mathrm{MPa}$ & 1.85 & $38.98 \mathrm{MPa}$ & 1.99 & 95.54 \\
\hline 5. & 90 days & 44.14 MPa & 1.95 & $42.96 \mathrm{MPa}$ & 2.06 & 97.32 \\
\hline
\end{tabular}

\subsubsection{Rapid Chloride Permeability Test (RCPT)}

This test is used to evaluate the performance of concrete against the chloride ion penetration. RCPT test (as shown in figure 5(a) and 5(b)) was conducted as per ASTM C1202 [29] on concrete disc specimens of size $100 \mathrm{~mm}$ diameter and $50 \mathrm{~mm}$ thickness. Three concrete specimens were tested at $28,56 \& 90$ days. The test setup consisted of two compartments or cells (cathode and anode) with a central hole of diameter $100 \mathrm{~mm}$ and the cylindrical disc specimen was placed firmly in between the two cells with the help of rubber washer. The cathode compartment was filled with $3 \% \mathrm{NaCl}$ solution and anode compartment was filled with $0.3 \mathrm{M} \mathrm{NaOH}$ solution. Electrode dipped in $\mathrm{NaCl}$ was connected to negative terminal of the power supply and that of $\mathrm{NaOH}$ to the positive terminal. A potential difference of $60 \mathrm{~V}$ DC was maintained across the ends of the specimen using a DC power source between the anode and cathode. The current was monitored up to 6 hours at an interval of 30 minutes. The current was measured and recorded using a data logger and the total charge passed through the specimen was computed by integrating the current and time. The total charge passing through the specimen gives a measure of resistance of the specimen to chloride ion penetration. The categorization of sample on the basis of charge passed is given in Table 7. Test results are tabulated in Table 8.

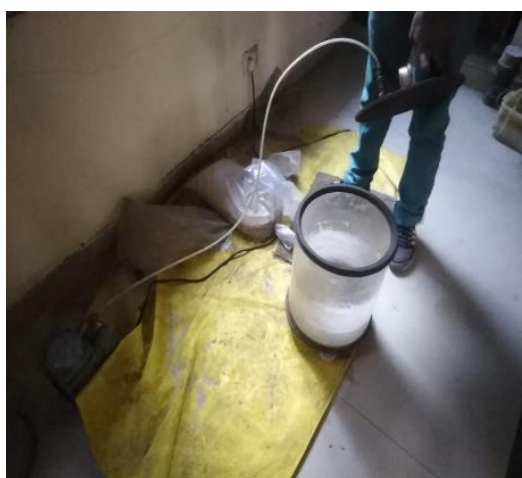

(a)

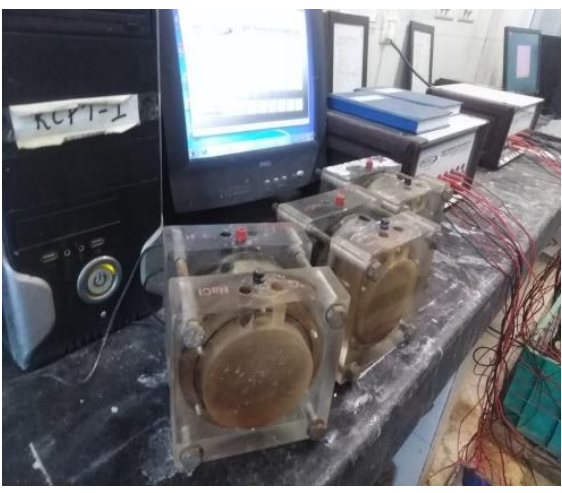

(b)

Fig. 5. (a) Vacuum box, (b) DC voltage system for RCPT tests 
The obtained value of charge passed in case of control mix lies in the range of 1,000-2000 coulombs corresponding to low permeability class as per ASTM C1202. However, the value is nearer to the lower limit of that class while in case of experimental mix the observed value lies in the range of 100-1000 coulombs corresponding to very low permeability class as per ASTM C1202. However, the value is nearer to the higher limit of that class. Thus, concrete made with LWGFAS has slightly improved performance in RCPT test compared to concrete made with natural sand.

Table 7. Chloride Ion Penetrability Based on Charge Passed

\begin{tabular}{ccc}
\hline Sl. No. & $\begin{array}{c}\text { Charge Passed } \\
\text { (Coulombs) }\end{array}$ & $\begin{array}{c}\text { Permeability Class as per } \\
\text { ASTM C1202 }\end{array}$ \\
\hline 1 & $>4,000$ & High \\
2 & $2,000-4,000$ & Moderate \\
3 & $1,000-2,000$ & Low \\
4 & $100-1000$ & Very Low \\
5 & $<100$ & Negligible \\
\hline
\end{tabular}

Table 8. RCPT Test Results

\begin{tabular}{cccc}
\hline $\begin{array}{c}\text { Sr. } \\
\text { No }\end{array}$ & $\begin{array}{c}\text { Age of } \\
\text { testing }\end{array}$ & $\begin{array}{c}\text { M25 with natural fine } \\
\text { aggregate (Control } \\
\text { Mix) }\end{array}$ & $\begin{array}{c}\text { M25 with 100\% replacement of natural } \\
\text { fine aggregate with LWGFAS } \\
\text { (Experimental Mix) }\end{array}$ \\
\hline 1. & 28 days & 1217 coulomb & 904 coulomb \\
2. & 56 days & 1198 coulomb & 895 coulomb \\
3. & 90 days & 1170 coulomb & 882 coulomb \\
\hline
\end{tabular}

The obtained value of charge passed in case of control mix lies in the range of 1,000-2000 coulombs corresponding to low permeability class as per ASTM C1202. However, the value is nearer to the lower limit of that class. The obtained value of charge passed in case of experimental mix lies in the range of 100-1000 coulombs corresponding to very low permeability class as per ASTM C1202. However, the value is nearer to the higher limit of that class. The pozzolanic behaviour of unreacted supplementary materials such as fly ash led to improvement in the pore chemistry of the concrete. However, since RCPT provides exaggerated results in case of pozzolanic materials, Rapid Chloride Migration Test was also conducted. The reduction in chloride penetration in the concrete made with LWGFAS sand is directly proportional to the concentration of $\mathrm{NaOH}$. In the experiment, geopolymer fly ash sand was manufactured by using $4 \mathrm{M} \mathrm{NaOH}$ while river sand did not have $\mathrm{NaOH}$. Thus due to presence of $\mathrm{NaOH}$, durability of the concrete improved.

\subsubsection{Chloride Migration Test After 28 Days as per NT Build 492}

In order to check the resistance of concrete against the chloride migration, NT Build 492 [30] test was conducted which is a non- steady state migration test. Three concrete specimens were tested at each age i.e. 28, 56 \& 90 days from each concrete mix. The specimens were subjected to a voltage of $30 \mathrm{~V}$ initially, which was adjusted according to the current measured initially, which could vary between 10 and $60 \mathrm{~V}$. The temperatures of the anodic solution were also measured at the beginning and at the end of the procedure. In the first stage of the test, the concretes are exposed to chlorides. After being subjected to ionic migration, the samples were diametrically broken and 0.1 M AgNO3 solution was sprayed on them to check the chloride penetration depth. Thereafter, the $D_{\text {nssm }}$ was calculated using: 


$$
\mathrm{D}_{\mathrm{nssm}}=\frac{0.0239(273+T) L}{(U-2 t)}\left(x_{D}-0.0238 \sqrt{\frac{(273+T) L x_{D}}{U-2}}\right)
$$

where $D_{n s s m}=$ non-steady state diffusion coefficient $\left(\times 10-12 \mathrm{~m}^{2} / \mathrm{s}\right) ; \mathrm{T}=$ average value of the initial and final temperatures in the anolyte solution $\left({ }^{\circ} \mathrm{C}\right) ; \mathrm{L}=$ thickness of the specimen $(\mathrm{mm}) ; \mathrm{U}=$ absolute value of the applied voltage $(\mathrm{V}) ; \mathrm{X}_{\mathrm{D}}=$ average value of the penetration depths $(\mathrm{mm})$; and $\mathrm{t}=$ test duration $(\mathrm{h})$

The test results are given in Table 9. The values obtained in case of control mix at 28, 56 \& 90 days are greater than the values obtained in case of the experimental mix containing LWGFAS sand. This can be attributed to improvement in the pore chemistry of the concrete due to the pozzolanic behaviour of unreacted supplementary materials such as fly ash in LWGFAS. This reflects improved behaviour of concrete against the chloride diffusion, made with $100 \%$ replacement of natural aggregate with LWGFAS.

Table 9. Chloride Migration Results

\begin{tabular}{ccc}
\hline Age of testing & $\begin{array}{c}\text { M25 with natural fine } \\
\text { aggregate (Control Mix) }\end{array}$ & $\begin{array}{c}\text { M25 with 100\% replacement of } \\
\text { natural fine aggregate with LWGFAS } \\
\text { (Experimental Mix) }\end{array}$ \\
\hline 28 days & $6.62 \times 10^{-12} \mathrm{~m}^{2} / \mathrm{s}$ & $4.65 \times 10^{-12} \mathrm{~m}^{2} / \mathrm{s}$ \\
56 days & $6.45 \times 10^{-12} \mathrm{~m}^{2} / \mathrm{s}$ & $4.23 \times 10^{-12} \mathrm{~m}^{2} / \mathrm{s}$ \\
90 days & $6.43 \times 10^{-12} \mathrm{~m}^{2} / \mathrm{s}$ & $4.16 \times 10^{-12} \mathrm{~m}^{2} / \mathrm{s}$ \\
\hline
\end{tabular}

\subsubsection{Bulk Conductivity as per ASTM C 1760}

This test method is used to determinate the bulk electrical conductivity of saturated specimens of hardened concrete to provide a rapid indication of the concrete's resistance to the penetration of chloride ions by diffusion [31]. This test method measures the electrical current through a saturated concrete specimen with a potential difference of 60 $\mathrm{V} \mathrm{dc}$ maintained across the ends of the specimen $(100 \mathrm{~mm}$ diameter and $200 \mathrm{~mm}$ height cylinders) at an age of 28 days. The current is measured 1 min after the voltage is first applied. The measured current, the applied voltage, and the specimen dimensions are used to calculate the bulk electrical conductivity of the concrete. Test results are given in Table 10. The difference between the bulk conductivity values of control mix and experimental mix is quite less. It suggests that the concrete prepared with LWGFAS is performing similar to concrete prepared with river sand against the passage of electric current through them. This indicates that the long term durability performance of LWGFAS will be similar to conventional aggregate.

Table 10. Results of Test of Bulk Conductivity as per ASTM C 1760

\begin{tabular}{ccc}
\hline $\begin{array}{c}\text { Age of } \\
\text { testing }\end{array}$ & $\begin{array}{c}\text { M25 with natural fine } \\
\text { aggregate (Control Mix) }\end{array}$ & $\begin{array}{c}\text { M25 with 100\% replacement of } \\
\text { natural fine aggregate with LWGFAS } \\
\text { (Experimental Mix) }\end{array}$ \\
\hline 28 days & 4.42 & 4.655 \\
\hline
\end{tabular}

\subsubsection{Volume of Air Permeable Voids}

The test is conducted on $50 \mathrm{~mm}$ thick concrete disc (diameter $100 \mathrm{~mm}$ ) at an age of 28 days. As per ASTM C 642 [32], the Standard Test Method for Density, Absorption, and Voids in Hardened Concrete, estimates the volume of permeable pore space in a hardened concrete specimen by determining the hardened concrete's density in different states (oven dry, saturated, saturated-boiled). Test results are given in table 11. A significantly higher value of volume of air permeable voids has been observed in the case of experimental mix. The observed behaviour may be caused due to high water absorbing nature of geopolymer fly 
ash sand. Thus, this is not a good parameter to compare the behaviour of concrete prepared with LWGFAS with concrete prepared with river sand.

Table 11. Results of Volume of Air Permeable Voids as per ASTM C 642

\begin{tabular}{ccc}
\hline $\begin{array}{c}\text { Age of } \\
\text { testing }\end{array}$ & $\begin{array}{c}\text { M25 with natural fine } \\
\text { aggregate (Control Mix) } \\
\text { Conductive }\end{array}$ & $\begin{array}{c}\text { M25 with 100\% replacement of } \\
\text { natural fine aggregate with LWGFAS } \\
\text { (Experimental Mix) }\end{array}$ \\
\hline 28 days & 7.66 & 16.06 \\
\hline
\end{tabular}

The results of volume of permeable voids are affected by a number of factors including compaction, curing, air entrainment, absorption and physical nature of the aggregate used. In Volume of Air Permeable Voids test, the observed value is higher which may be attributed to high water absorption of light weight geopolymer fly ash sand.

\subsubsection{Accelerated Carbonation Test}

Accelerated Carbonation test (ACT) was conducted on concrete beam specimen with dimension $100 \times 100 \times 500 \mathrm{~mm}$ as per ISO 1920 Part 12 [33]. After 28 days of water curing, the concrete specimens were shifted to laboratory environment (temperature $=27 \pm 2{ }^{\circ} \mathrm{C}$ and relative humidity $=65 \pm 5 \%$ ) for 14 days. After 42 days of laboratory conditioning, top and bottom longitudinal faces and two end faces of the beam were sealed using paraffin wax and carbonation was allowed on two cast longitudinal faces, in order to prevent multidirectional carbonation. After the sealing, the concrete beam specimens were shifted to the carbonation chamber (as shown in figure 6 ) having $4 \pm 0.5 \%$ concentration of carbon dioxide, temperature $=27+2{ }^{\circ} \mathrm{C}$ and relative humidity of $65 \pm 5 \%$. The carbonation depth was measured after 70 days of exposure, by approximately cutting a slice of $50 \mathrm{~mm}$ thick from the concrete beam specimen and exposing the cut surface to $1 \%$ phenolphthalein solution. Test results have been tabulated in table 12 .

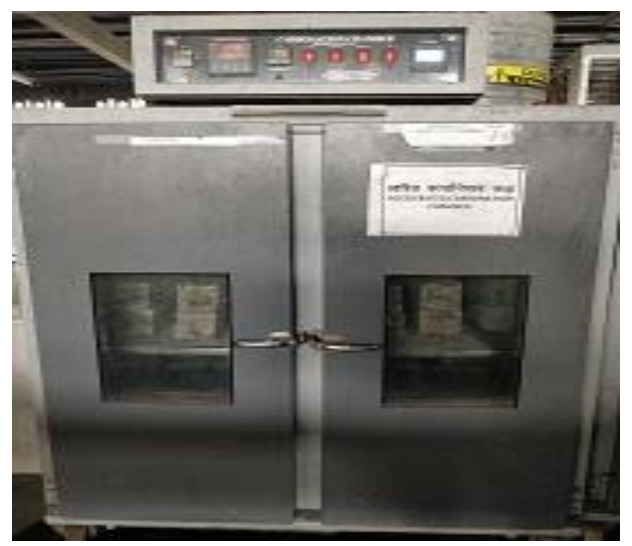

Fig. 6. Carbonation Chamber for Accelerated Carbonation Test 
Table 12. Results of Accelerated Carbonation Test (ACT)

\begin{tabular}{ccc}
\hline Age of testing & $\begin{array}{c}\text { M25 with natural fine } \\
\text { aggregate (Control mix) }\end{array}$ & $\begin{array}{c}\text { M25 with 100\% replacement of natural } \\
\text { fine aggregate with light weight } \\
\text { geopolymer fly ash sand. }\end{array}$ \\
\hline 70 Days & $8.2 \mathrm{~mm}$ & $2.1 \mathrm{~mm}$ \\
\hline
\end{tabular}

The obtained value of carbonation depth of mix containing LWGFAS is lower than the carbonation depth obtained in control mix, which reflects improved behaviour of experimental concrete mix against carbonation. In case of GFS concrete, carbonation might have produced sodium carbonate products [34], and these sodium carbonate may have reduced the $\mathrm{pH}$ of the concrete by maximum 11, while, in case of river sand, the carbonation might have produced calcium carbonate, and these calcium carbonate may have reduced the $\mathrm{pH}$ of the concrete by less than 9 causes formation of $\mathrm{CaCO}_{3}$ [35]. The GFS sand has high $\mathrm{pH}$ value as compared to the river sand concrete. The increased $\mathrm{pH}$ and the formation of the sodium carbonates may have protected the concrete from carbonation, hence improving the durability of the concrete and hence improving the service life of the concrete.

\subsubsection{Drying Shrinkage}

This test was conducted on concrete beam (length $300 \mathrm{~mm} \&$ cross section $75 \times 75 \mathrm{~mm}$ ), water cured for 28 days as per IS 1199 [36, 37]. Test results for drying shrinkage at 28 days have been tabulated in table 13. The obtained value of drying shrinkage in case of mix containing LWGFAS is similar and comparable to the drying shrinkage obtained in control mix containing $100 \%$ natural aggregates, which shows that there is no negative impact of use of geopolymer as fine aggregate in concrete in terms of drying shrinkage.

Table 13. Results of Drying Shrinkage

\begin{tabular}{ccc}
\hline Age of testing & $\begin{array}{c}\text { M25 with natural fine aggregate } \\
\text { (Control mix) }\end{array}$ & $\begin{array}{c}\text { M25 with 100\% replacement } \\
\text { of natural fine aggregate with } \\
\text { LWGFAS. }\end{array}$ \\
\hline 28 Days & $0.0162 \%$ & $0.0163 \%$ \\
\hline
\end{tabular}

Since the LWGFAS concrete had higher water absorption as compared to the river sand it necessitated to analyze the drying shrinkage of the concrete. The reason for the comparable drying shrinkage though the large water absorption may be due to the 'block polymerization' concept as in case of geopolymer concrete. The Silica and Alumina in the fly ash polymerizes with the liquid solution thus forming "blocks" containing geopolymer binders causing increase in the aggregate content of the concrete. This may also be the case with concrete made with LWGFAS sand. The alkaline liquid and the fly ash may have reacted and formed blocks which helped in filling the porosity of the concrete thus improving the durability properties of the concrete made with LWGFAS as replacement of natural sand.

\subsection{Mortar Properties}

This test was conducted on mortar cubes (of size $50 \mathrm{~mm} \times 50 \mathrm{~mm} \times 50 \mathrm{~mm}$ ) as per IS: 2250 1981 [38] in the ratio 1:3, 1:4 and 1:6 and tested for compressive strength at 7 and 28 days. The test results are given below in table 14. All the samples of mortar made with $100 \%$ replacement of natural fine aggregate with Light Weight Geopolymer Fly Ash Sand conform to the strength requirements as per IS 2250:1981. In case of mortar (ratio 1:3) made with $100 \%$ replacement of natural fine aggregate with LWGFAS, the strength at 7 days and 28 days is $38.11 \%$ and $38.70 \%$ respectively to that of control sample. In case of mortar (ratio 1:4) made with $100 \%$ replacement of natural fine aggregate with Light Weight Geopolymer Fly Ash Sand, the strength at 7 days and 28 days is $54.53 \%$ and $59.77 \%$ respectively to 
that of control sample. In case of mortar (ratio 1:6) made with 100\% replacement of natural fine aggregate with LWGFAS, the strength at 7 days is $63.17 \%$ to that of control sample. However, at 28 the strength at 7 days is $63.17 \%$ to that of control sample. Use of $\mathrm{NaOH}$ solution of lower concentration and only 1 hour of post set heat treatment at $100^{\circ} \mathrm{C}$ for preparation of LWGFAS in this study led to lower specific gravity and higher water absorption, which might be the reason for lower compressive strength of experimental mixes containing LWGFAS in comparison to control mortar mixes containing natural sand.

Table 14. Test Results of Studies Conducted on Mortar

\begin{tabular}{|c|c|c|c|c|c|}
\hline $\begin{array}{l}\text { Sr. } \\
\text { No. }\end{array}$ & $\begin{array}{l}\text { Mortar } \\
\text { Mix }\end{array}$ & $\begin{array}{l}\text { Age of } \\
\text { testing }\end{array}$ & $\begin{array}{c}\text { Mortar } \\
\text { with } \\
\text { natural } \\
\text { fine } \\
\text { aggregate } \\
\text { (Control } \\
\text { Mix) }\end{array}$ & $\begin{array}{l}\text { Mortar with } 100 \% \\
\text { replacement of } \\
\text { natural fine } \\
\text { aggregate with } \\
\text { Light Weight } \\
\text { Geopolymer Fly } \\
\text { Ash Sand } \\
\text { (Experimental } \\
\text { Mix) }\end{array}$ & $\begin{array}{l}\text { Percentage } \\
\text { Compressive } \\
\text { Strength } \\
\text { (Experimental } \\
\text { Mix/Control } \\
\text { Mix)*100 }\end{array}$ \\
\hline \multirow[t]{2}{*}{1.} & M1 $(1: 3)$ & 7 days & 19.18 & 7.31 & 38.11 \\
\hline & & 28 days & 27.83 & 10.77 & 38.69 \\
\hline \multirow[t]{2}{*}{2.} & M2 (1: 4) & 7 days & 12.36 & 6.74 & 54.53 \\
\hline & & 28 days & 17.85 & 10.67 & 59.77 \\
\hline \multirow[t]{2}{*}{3.} & M3 $(1: 6)$ & 7 days & 7.74 & 4.89 & 63.17 \\
\hline & & 28 days & 14.68 & 8.45 & 57.56 \\
\hline
\end{tabular}

\section{Conclusions}

Based on literature studied and experimental investigation done in the paper, following conclusions can be drawn:

- The light weight geopolymer fly ash sand was characterized and was used as a replacement of natural fine aggregate for preparation of concrete and mortar mixes and their performance was evaluated for various hardened and durability properties of concrete and mortar. The results have been compared with similar sample prepared with river sand.

- $\quad$ The LWGFAS was manufactured by preparing alkaline activator solution using 4 $\mathrm{M} \mathrm{NaOH}$ solution and $\mathrm{Na}_{2} \mathrm{SiO}_{3}$ : $\mathrm{NaOH}$ ratio as 2:1 and mixing this with fly ash.

- The LWGFAS showed similar properties as that of river sand except it had less specific gravity and high water absorption. The higher value of water absorption indicates presence of voids in its structure.

- The compressive strength of concrete mixes prepared with light weight geopolymer fly ash sand was observed to improve with age. At 28 days LWGFAS concrete attained $74.90 \%$ strength as that of river sand concrete whereas at 90 days $97.32 \%$ strength was achieved indicating a continuous gain of strength in the GFS concrete.

- In terms of different durability related parameters such as RCPT, chloride migration test, bulk conductivity, accelerated carbonation test and drying shrinkage, experimental mixes containing light weight geopolymer fly ash sand as a replacement of natural aggregates showed comparable or better performance in comparison to their corresponding control concrete mixes containing $100 \%$ natural aggregates. Significant reduction in chloride permeability was observed 
in case of GFS concrete as compared to the river sand concrete. The chloride migration test also portrayed the similar result as that of rapid chloride penetration test. The accelerated carbonation test displayed a 4 times reduction in carbonation with the use of LWGFAS concrete. The higher water absorption though did not influenced the drying shrinkage of the concrete thus making GFS suitable as an alternative to river sand.

- In case of mortar samples, the experimental mix containing light weight geopolymer fly ash sand conform to their respective strength requirements of mortar but are lower in comparison to control mix containing natural fine aggregates. Current and past studies indicate that compressive strength of concrete and mortar mixes containing light weight geopolymer fly ash sand can be improved if activator solution of slightly higher concentration and increased post set heat treatment duration is used for preparation of light weight geopolymer fly ash sand. For normal grade concrete (in the range of M20 to M30), geopolymer fly ash sand can be a viable and sustainable solution.

- The study indicates that Geopolymer fly ash sand can be suitable for a wide range of applications in making concrete ranging from light weight in nature to normal weight concrete based on the physical and chemical characteristics of Geopolymer fly ash sand.

\section{Acknowledgement}

The authors would like to acknowledge Visvesvaraya National Institute of Technology (VNIT Nagpur) for providing light weight geopolymer fly ash sand for the above study.

\section{References}

[1] Wang R, Yu N, Li Y. Methods for improving the microstructure of recycled concrete aggregate: A review, Construction and Building Materials, Volume 242, May 2020

https://doi.org/10.1016/i.conbuildmat.2020.118164

[2] Palomo, Grutzeck MW, Blanco MT. Alkali-activated Fly Ashes A cement for the future, Journal of Cement and Concrete Research, 1999, Vol. 29, pp. 1323-1329. https://doi.org/10.1016/S0008-8846(98)00243-9

[3] World Business Council for Sustainable Development, Recycling Concrete-The Cement Sustainability Initiative Report, 2009.

[4] Donza H, Cabrera O, Irassar EF. High-strength concrete with different fine aggregate, Cement and Concrete Research, 2002; 32: 1755-1761. https://doi.org/10.1016/S0008-8846(02)00860-8

[5] Hardjito D, Wallah SE, Sumajouw DMJ, Rangan BV. Fly Ash-Based Geopolymer Concrete Australian Journal of Structural Engineering, January 2005; 6:1, 1-10. https://doi.org/10.1080/13287982.2005.11464946

[6] Report on Fly Ash Generation at Coal/ Lignite Based Power station and its Utilization in the Country for the Year 2014-15, Centre Electricity Authority, New Delhi, October 2015.

[7] Dasha MK, Patro SK, Ratha AK. Sustainable use of industrial-waste as partial replacement of fine aggregate for preparation of concrete - A review, International Journal of Sustainable Built Environment, 2016; 5:2, $484 \quad$ - 516. https://doi.org/10.1016/j.ijsbe.2016.04.006

[8] James MN, Choi W, Abu-Lebdeh T. Use of Recycled Aggregate and Fly Ash in Concrete Pavement, Am. J. Engg. \& Applied Science, 2011; 4: 201 - 208 https://doi.org/10.3844/ajeassp.2011.201.208

[9] Toshiki A, Osamu K, Kenji S. Concrete with copper slag fine aggregate, J. Soc. Mater. Sci. 2000; 49; 1097 - 1102. https://doi.org/10.2472/jsms.49.1097 
[10] Nisnevich M, Sirotin G, Dvoskin L, Fishel J. Using High-Volume Fly Ash in Lightweight Concrete with Bottom Ash as Aggregate, Proceeding of the Seventh CANMET/ACI International Conference on Fly Ash, Silica Fume, Slag and Natural Pozzolans in Concrete, 2001, Madras, India, 99 - 114.

[11] IS 9142 Part 2:2018, Artificial lightweight aggregate for concrete - Sintered fly ash coarse aggregate.

[12] Palomo A, Macias A, Blanco MT, Puertas F. Physical, Chemical and Mechanical Characterization of Geopolymer, Proceedings of the 9th International Congress on the Chemistry of Cement, New Delhi, India, 23-28 November 1992.

[13] Duxson P, Lukey GC, Deventer V. Physical evolution of Na-geopolymer derived from metakaolin up to $1000^{\circ}$, Journal of Material Science. 2007; 42: 3044 - 3054 https://doi.org/10.1007/s10853-006-0535-4

[14] Davidovits J. Geopolymer, Chemistry and Applications, 3rd ed.; Institute Geopolymer: Saint-Quentin, France, 10 - 11, 2011.

[15] Ferone C, Colangelo F, Cioffi R, Montagnaro F, Santoro L. Mechanical performances of weathered coal fly ash based geopolymer bricks, Procedia Eng. 2011; 21: 745 - 752. https://doi.org/10.1016/j.proeng.2011.11.2073

[16] Hardjito D, Wallah SE, Sumajouw DMJ, Rangan BV. Fly Ash-Based Geopolymer Concrete, Australian Journal of Structural Engineering, January 2005; 6:1, 1 - 10. https://doi.org/10.1080/13287982.2005.11464946

[17] Rao SM, Acharya IP. Synthesis and characterization of fly ash geopolymer sand, Journal of Materials in Civil Engineering, 2014; 26:2, 186 - 190. https://doi.org/10.1061/(ASCE)MT.1943-5533.0000880

[18] Agrawal US, Wanjari SP, Naresh DN, Characteristic study of geopolymer fly ash sand as a replacement to natural river sand, Construction and Building Materials, 2017; 150: 681 - 688. https://doi.org/10.1016/j.conbuildmat.2017.06.029

[19] Agrawal US, Wanjari SP, Naresh DN. Impact of replacement of natural river sand with geopolymer fly ash sand on hardened properties of concrete, Construction and Building Materials 2019; 209: 499 - 507. https://doi.org/10.1016/j.conbuildmat.2019.03.134

[20] Wanjari SP, Agrawal US, Naresh DN. Geopolymer Sand as a replacement to Natural Sand in concrete, 14th International Conference on Concrete Engineering and Technology, IOP Conf. Series: Materials Science and Engineering 431, 2018. https://doi.org/10.1088/1757-899X/431/9/092011

[21] IS 2386 Part 8-1963, Methods of Test for Aggregates for Concrete - Part VIII: Petrographic Examination.

[22] ASTM C1260- 2014, Standard Test Method for Potential Alkali Reactivity of Aggregates (Mortar-Bar Method).

[23] IS 383-2016, Coarse and fine aggregate for concrete-specifications.

[24] ACI 213R-2014, Guide for Structural Lightweight-Aggregate Concrete.

[25] ASTM C1293:2020a, Standard Test Method for Determination of Length Change of Concrete Due to Alkali-Silica Reaction.

[26] IS 269-2015, Ordinary Portland Cement - Specification, Bureau of Indian Standards, New Delhi

[27] Agrawal US, Wanjari SP, Naresh DN, Characteristic study of geopolymer fly ash sand as a replacement to natural river sand, Construction and Building Materials, 2019; 150: 681 -688. https://doi.org/10.1016/j.conbuildmat.2017.06.029

[28] Rao SM, Acharya IP, Synthesis and characterization of fly ash geopolymer sand, Journal of Materials in Civil Engineering, 2014; 26:2, 186 - 190. https://doi.org/10.1061/(ASCE)MT.1943-5533.0000880

[29] ASTM C1202 - 2017a, Standard Test Method for Electrical Indication of Concrete's Ability to Resist Chloride Ion Penetration.

[30] NT BUILD 492, Chloride migration coefficient from non-steady-state migration experiments. 
[31] ASTM C1760-2012, Standard Test Method for Bulk Electrical Conductivity of Hardened Concrete.

[32] ASTM C642-2013, Standard Test Method for Density, Absorption, and Voids in Hardened Concrete.

[33] ISO 1920 Part 12 (2015). Determination of Carbonation resistance of concrete.

[34] Palomo A, Gonza JA, Bastidas DM, Ferna A, A study on the passive state stability of steel embedded in activated fly ash mortars, Corr. Sci., 2008; 50: 1058 - 1065. https://doi.org/10.1016/j.corsci.2007.11.016

[35] Law DW, Arham A, Thomas A, Patnaikuni I, Wardhono A, Long term durability properties of class F fly ash geopolymer concrete, Mater. Struct. 2015; $721-731$. https://doi.org/10.1617/s11527-014-0268-9

[36] 1S 1199-2004. Method of sampling and analysis of concrete.

[37] Ojha PN, Singh B, Singh A, Patel V, Arora VV, "Experimental study on creep and shrinkage behavior of high strength concrete for application in high rise buildings", Indian Concrete Journal, 2021; 95 (2), 30-42.

[38] IS 2250-1981, Code of practice for preparation and use of masonry mortars (First Revision). 